\title{
Outdoor és élménykereső irányzatok: Szabadítsuk ki a gyerekeket!
}

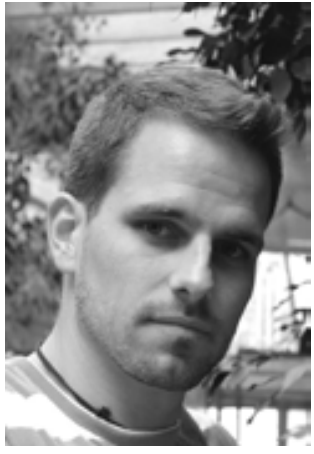

Abstract: To get back a good physical condition and restore the physical activity to the students life the government introduced the new 27th public education law about Daily physical education under $\S(11)$ in the first, fifth, and ninth grade of school education. Students willingness to participate in physical education classes are in decline and they consider the lessons boring. To recreate their health consciousness and to evolve their need to daily movement we have to develop newer, in some respects more modern, techniques more accepted abroad should be applied in our education system. For the successful introduction of these methods, supported by various research results we can provide some help for the unprepared education system. As possibility provided by the law they are offered external physical education, freely usable unprepared lessons and the opportunity to centralize these lessons. My research indicates that schools, parents and students are also open to these kind of training opportunities, Over $90 \%$ of the interviewed parents and children consider using these methods very positive. With this clearly proving that they want to see the potential of these kind of teaching methods were available to them. The interviewed teachers and institutional staff unanimously agreed that these methods would be good for the children, and even themselves.

Key words: Outdoor, experimental education, public education

Történetem 2010-ben kezdődött, amikor is egy alapítványi iskolának tartottunk Szabadtéri Tréning programot. A feladatunk egyszerű volt; egy a felnőttek számára készített évek óta játszatott tematikus „csapatépítő” játékot kellett átalakítanunk a diákok számára. A program rendkívül sikeres volt, azóta is minden évben legalább egyszer megrendezésre kerül egy ehhez hasonló egy napos program, ugyanazon iskola más és más diákcsoportjai számára. Rögtön az első program után felmerült bennem, hogy vajon hogyan lehetne elérhetővé tenni ezt minden közoktatásban szereplő tanuló számára. A probléma megoldására azonban akkor még nem volt lehetőség, ám a terveket nem vetettem el. Egyre alaposabb kutatás vette kezdetét, míg végül a lehetőséget egy 2012-ben a köznevelési törvény és egyéb rendeletek létrejötte, megváltoztatása nyújtotta...

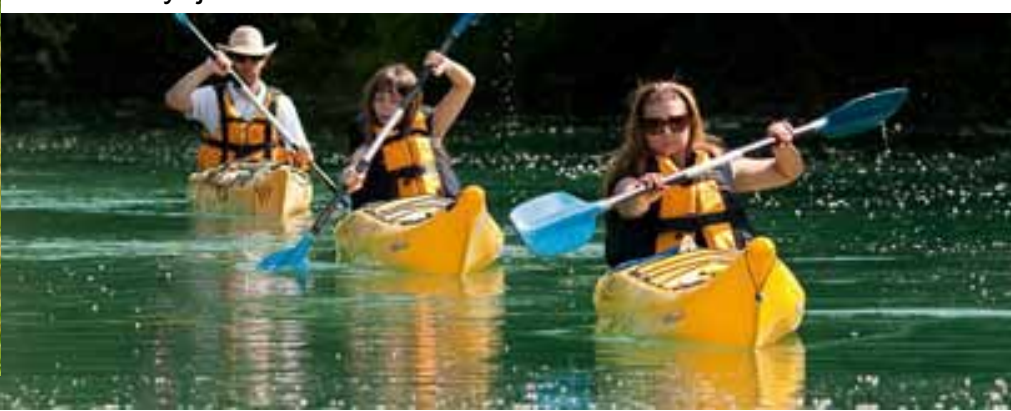

A jó fizikai állapot visszaállítására és a fizikai aktivitás megszerettetésére vezették be az új köznevelési törvény 27 . $§$ (11) bekezdés szerinti mindennapos testnevelést az iskolai nevelés-oktatás első, ötödik, kilencedik évfolyamán 2012. szeptember 1-jétől kezdődően felmenő rendszerben. A tervezetet alapvetően pozitív hangulat fogadta, azonban a rendszerrel több probléma adódik. A 2013.04.18-án megtartott Szabadidősport Konferencia előadási között elhangzott, hogy 
a diákok hajlandósága hanyatlik a testnevelés órákon való részvételre és „unalmasnak” tartják a foglalkozásokat. Ha ebből a szempontból világítunk a mindennapos testnevelésre, rögtön láthatjuk, hogy nem olyan fényes a helyzet és egyáltalán nem biztos, hogy a kívánt hatást érheti el a törvény. A diákok megfelelő egészségtudatának és mozgásigényének kialakításához újabb, bizonyos tekintetben modernebb, külföldön elfogadottabb módszereket kellene alkalmazni a hazai oktatásban. Miért ne használhatnánk fel a természet adta lehetőségeket az amúgy is szükös iskolák helyett? A következő problémát a már említett oktatási intézmények felkészítetlensége okozza. Számos iskolának szükös a kapacitása ekkora létszámú diákság, folyamatos testnevelés oktatására. Sem a financiális sem a humán erőforrások nem teszik lehetővé az osztályok folyamatos foglalkoztatását, ráadásul még be sem kapcsolódott minden évfolyam. Az iskolai testnevelés alatt én azokat a foglalkozásokat értem, ahol a Nemzeti Alaptanterv Testnevelés és sport müveltségterületének előírásait alkalmazni kell. De ez nem a mindennapos testnevelés, csak abban az esetben, ha az iskola minden órát meg tud szervezni műveltségterületi oktatással. Ha nem, akkor jön a hetenkénti kettő, kiváltható óra, ahol már nem érvényesülnek a NAT és a kerettantervek szabályai.

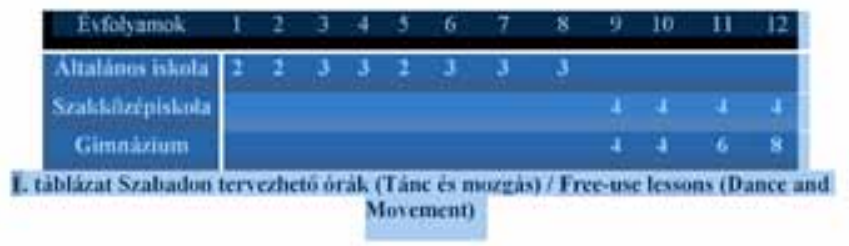

Több iskola jelenleg csak olyan módon tudja megoldani az 5 kötelező testnevelés óra megtartását, hogy 3+2-es rendszerbe bontja azokat. Ez azt jelenti jelenleg a gyakorlatban, hogy az iskola saját keretein belül biztosít 3 testnevelés óra lebonyolításához szükséges erőforrást, a maradék 2-őt pedig a diáknak saját magának, illetve a diáknak és a szülőnek kell megoldania. Természetesen segítséget ebben kapnak. A 2, akár „külsős helyszínen” megtartott testnevelés óráról elfogadható igazolást azonban csak, egyesületi háttérrel rendelkező mozgásformákkal foglalkozó szervezet állíthat ki jelen pillanatban.

Ez alapvetően remek lehetőség, azonban jelenleg ilyen foglalkozások megtartására hivatalosan a köznevelési törvény csak az iskolai sportköri foglalkozásokat, valamint a versenysport területén müködő sportszervezetekben végzett edzést nevesítette potenciális alternatívaként így az élsport területén tevékenykedő szervezetek kaptak engedélyt. Testnevelési rendszerünk alapvetően a kötelező műveltségterületi tudásanyag elsajátítására helyezi a hangsúlyt és az ebben tehetséges diákok számára biztosít bizonyos kiugrási lehetőséget. Mondhatnánk majdhogynem, tehetséggondozás folyik az iskolákban. Biztosan, jó az, ha ehhez nagymértékben utánpótlás neveléssel foglalkozó egyesületeket kapcsolunk? Természetesen az élsport fejlesztéséhez ez remek lehetőség — ez mindenki számára világos — azonban a jogalkotók látták, hogy ez még mindig nem elég, hiszen épp azoknak a gyerekeknek nem volt ez megoldás, akik kevéssé tehetségesek a sportban. Ugyanis köztudottan az iskolai sportkörökben és a sportegyesületekben, sportvállalkozásokban is tehetséggondozási tevé- kenység folyik többnyire. Mi van tehát a gyerekek, tanulók tömegével, akik nem az „élsportban” tehetségesek? Az ő egészségfejlesztésük nem fontos?

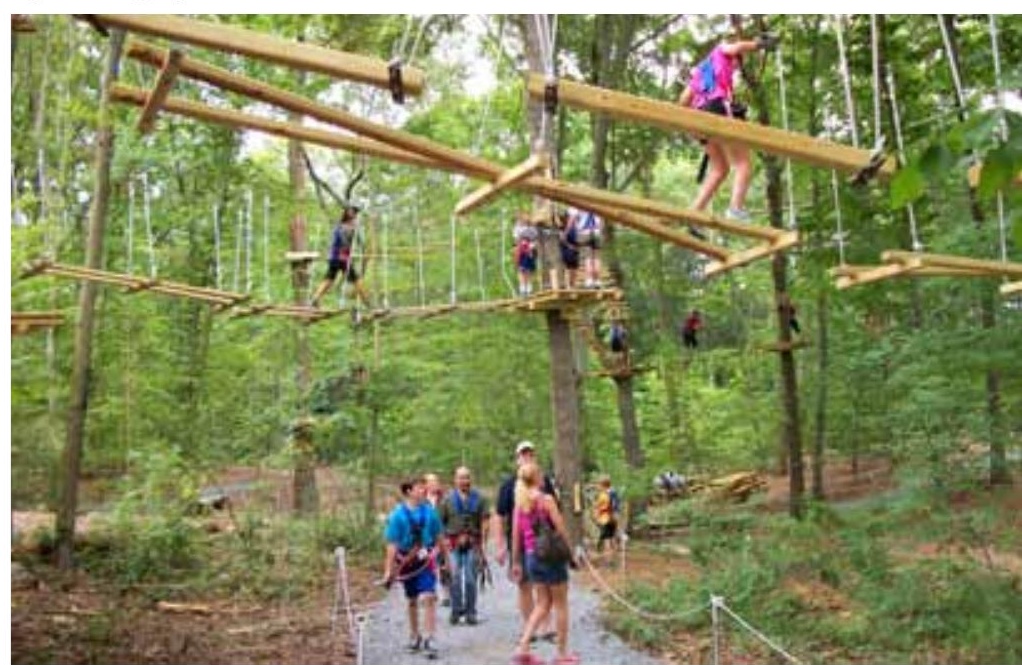

Fontos lenne, hogy rekreatív egész életúton át tartó mozgásszükséglet kialakítása már fiatal korban megtörténjen, hiszen így van esélyük arra, hogy később egészséges, egészségtudatos felnőttekké váljanak. A különböző szabadtéri és élménykereső irányzatok nyújtotta mozgásformák között szinte biztosan találnának olyat, amely egész életük során kikapcsolódást, rekreálódási lehetőséget nyújthat számukra, melyböl maga az állam is profitálhat, hiszen ez elősegítheti a rekreatívan, egészségtudatosan sportoló nemzetté válást Ezt próbálja a köznevelési törvény 2014. január 1-töl hatályos módosítása kezelni (a Magyar Közlöny 2013. december 23-án megjelent 218. számában közzétették az egyes törvényeknek a gyermekek védelme érdekében történő módosításáról szóló 2013.évi CCXLV. törvényt, ami a nemzeti köznevelési törvény egyes részeit is módosítja), ami az egyesületben végzett sportolást is alternatívaként fogadja el. Itt már nem rögzíti a jogalkotó, hogy versenysport területén kell müködnie a sportszervezetnek, ebből fakadóan a rekreációs, szabadidős sportszervezetek által nyújtott szolgáltatások is nyitva lesznek a mindennapos testnevelés heti két órája kapcsán.

De hogyan valósulhat meg ez az egész?

$\mathrm{Az}$ iskolai testnevelés kapcsán ezek a mozgásformák minden további nélkül a müveltségterületi oktatás részét képezhetik, amennyiben megfelelnek bizonyos feltételeknek, kritériumoknak. Az első és legfontosabb, hogy azt képviselő szervezetek bizonyítani tudják azt, hogy az egyes évfolyamokon a program illeszthető a NAT-hoz és a kerettantervekhez (differenciáltan: 1-4., 5-8., és 9-12. évfolyamokon), pedagógiailag megalapozott programot dolgoznak ki, és lehetőség szerint a kerettantervekbe tudják integrálni azt. Ehhez természetesen megfelelő, meglévő infrastruktúra és eszközellátottság szükséges. (épített környezet, megfelelő hitelesített felszerelések megléte, biztonságtechnikai szabályozások stb.) Tipikus példa erre az IAAFA Magyar Atlétikai Szövetség által adaptált Kölyökatlétikai programja. Az efféle tanórán kívüli foglalkozások tekintetében az a probléma, hogy a korábbi években számos szereplő élt jól ebből a teljesen szabályozatlan területből, és nem volt semmilyen minőségi kontroll e szereplők tevékenysége fölött. $A$ 20/2012 EMMI rendelet az első, ami a minőségbiztosítási 
feladatokkal az Országos Egészségfejlesztési Intézetet ruházza fel. A rendelet ebben a tekintetben szintén módosításra kerül majd, de alapvetően elindult legalább egy folyamat, aminek jó eredménye lehet. Ez viszont azt feltételezi, hogy bármely iskolán kívüli szervezet, vagy személy kíván iskolai egészségfejlesztési programot megvalósítani, ahhoz előbb át kell, hogy essen az OEFI (Országos Egészségfejlesztési Intézet) rostáján. A tanórán kívüli testmozgás kapcsán pedig a megjelenő TÁMOP-6.1.2 kiemelt projektben lesz mód elvégezni az ehhez szükséges módszertani fejlesztéseket. Több jelenleg is a piacon lévő outdoor mozgásformákkal foglalkozó cég-, egyesület képviselőivel, szakemberrel, végzett hallgatóval beszéltem azonban szinte egyikük sem tudott arról, hogy efféle módon lehetne bekerülni az iskolai oktatási rendszerbe. Ugyanakkor szívesen színesítenék a testnevelést ilyen foglalkozásokkal.

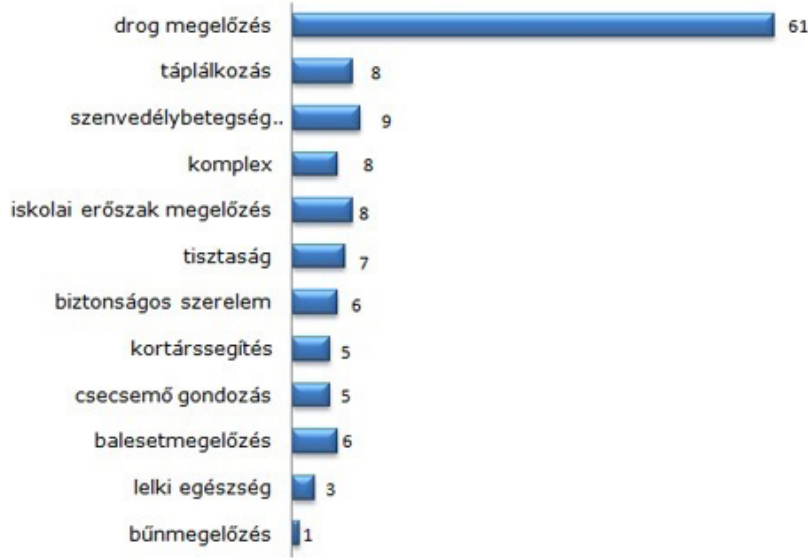

1. ábra Kérelmek téma szerinti megoszlása / Distribution of applications by subject forrás: http://www.oefi.hu/iskolaiprajanlas/iskolaiprogramokajanlasa_9.html

Az OEFI honlapján kutatva, hamar megtalálhatjuk a 2013. február 1-je és 2013. augusztus 31-e között Iskolai egészségfejlesztési programra benyújtott kérelmeket. 45 szervezet nyújtott be 127 tanulmányt az Országos Egészségfejlesztési Intézethez. Ezek közel fele, 61 db drog megelőzési program volt és meglehetősen kevés foglalkozott az egészséges mozgásigény kialakításával. A beérkezett tervek $85 \%$-a azonban elutasításra került részben a Döntési Bizottság valamint formális okokból kifolyólag.

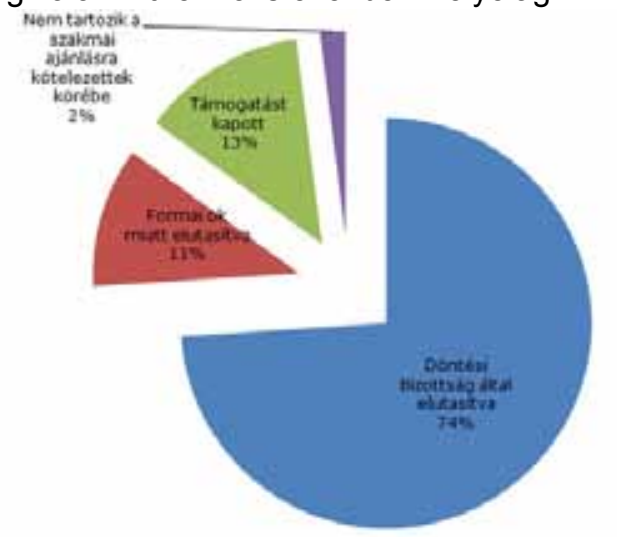

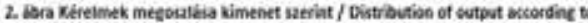

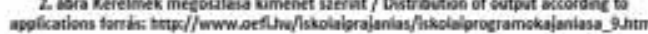

„Az eddigi tapasztalatok alapján a legkomolyabb kihívást a célok pontos megfogalmazása, a célok elérését jellemző mutatók (indikátorok) hozzárendelése, továbbá a monitorozás és értékelés cél- és eszközrendszerének a keveredése, valamint a célrendszertől való függetlenedése jelentette a kérelmezők számára. További gyakori probléma volt az adatvédelmi jogszabályoknak való meg nem felelés, pl. szülői beleegyező nyilatkozatok elmaradása különösen érzékeny adatok felvételének szándéka esetén az érintett korcsoportok diákjaitól, továbbá egyes, önmagukban egészségfejlesztő hatással nem bíró programelemek kérelemre benyújtása." (http://www.oefi. hu/iskolaiprajanlas/iskolaiprogramokajanlasa_9.html)

Előzetes kutatásiam alapján melyet, „Az Outdoor és élménykereső irányzatok, mint élménypedagógiás módszerek fontossága az egészséges életmódra nevelésben, behelyezési lehetőségük a közoktatásba" címü diplomadolgozatomhoz végeztem, a megkérdezett iskolák, diákok, szülők, szolgáltatók és egyesületek is nyitottak lennének az ilyen lehetőségek közoktatásba történő integrálása felé. A kutatásaimhoz 211 szülő és 157 diák töltött ki az ország 6 különböző helyszínén kérdőívet valamint 10 közép és általános iskolai testnevelő tanárait sikerült elérnem. A kérdőívek mellett riportokat, interjúkat is készítettem a témakörrel kapcsolatban. Így a mintám nagysága közel 400 fő volt. A kérdőíveket elemezve a válaszadó diákok 97\%-a szeretné, ha iskolájukban, az iskolájuk környékén megjelenne efféle lehetőség. Míg a szülők $80 \%$-a szívesen látna szabadtéri újító, változatos mozgásformákat az iskolai testnevelésben. Riportalanyaim, interjúalanyaim között szerepelt 4 hazai outdoor szolgáltató cég képviselője, akik bármikor átalakítanák, bővítenék jelenlegi programjaikat a diákok számára. Kutatásaimból nem hagyhattam, ki a vezető szervezetek képviselőit sem. Interjúk készültek Dr. Molnár Lászlóval (MDSZ), Dr. Hamar Pállal (MTA), Varga Ádámmal (KLIK). Az interjúk során egyértelmüen pozitívan nyilatkoztak a témával kapcsolatban és válaszaik számos új megvilágításba helyeztek néhány kérdést. Azonban abban mindannyian egyet értettek, hogy ez egy jó irány lenne. Dr. Molnár László külön kiemelte, válaszában, hogy a Magyar Diáksport Szövetség álláspontja nagyon közel áll kutatásaimhoz; jelenleg a magyar testnevelés teljes megreformálásán dolgoznak, mely projekt az elkövetkezendő években, fog kiteljesedni.

Az outdoor mozgásformák behelyezése a közoktatásba egy nagyon kétoldalú lehetőség! A diákok közül szinte mindenki megtalálhatná a neki tetsző mozgásformát az outdoor sportok végtelenül színes világából ugyanakkor a megfelelő támogatási- és törvényi szabályrendszer kialakításával a szolgáltatók megélhetése is stabilabb lenne a hazai piacon. Mindenképpen állami szinten kellene foglalkozni OEFI által biztosított minőségbiztosítási rendszer megismertetésével, az ezekhez tartozó pályázati anyagok helyes kialakításával, valamint átláthatóságuk egyszerüsítésével. Ezen lépések megtételével számos lehetőség nyílna a hagyományos testnevelés órák anyagának felfrissítésére és a felnövekvő generációk, nagyobb eséllyel vehetnének részt (tudtukon kívül) a Sportoló Nemzetté alakulásban!

Hivatkozások:

Eduline (2013.01.29)

From: www.eduline.hu/kozoktatas/2013/1/29/uj_kerettantervek_kozoktatas_tantargyak_ora_BO74EW

OEFI (2013) From: http://www.oefi.hu/iskolaiprajanlas/ iskolaiprogramokajanlasa_9.html

From: http://www.oefi.hu/iskolaiprajanlas/ iskolaiprogramokajanlasa_9.html 